\title{
EXPERIMENTAL EVIDENCE OF SULFIDE MELT EVOLUTION VIA IMMISCIBILITY AND FRACTIONAL CRYSTALLIZATION
}

\author{
JOHN MAVROGENES ${ }^{\S}$ \\ Research School of Earth Sciences Australian National University Canberra, Australia \\ RONALD FROST \\ University of Wyoming \\ HEATHER A. SPARKS \\ Research School of Earth Science Australian National University Canberra, Australia
}

\begin{abstract}
Most ore deposits in high-grade metamorphic terranes show signs of remobilization of sulfide ores. During this process the compositions and tenor of the ore changes dramatically. In this report we show the results of a study designed to clarify chemical modification of sulfide melts as they cool from high temperatures. Sulfide melts were allowed to "trickle down" through a permeable inert host over an extreme temperature gradient. The effects of crystal fractionation and liquid immiscibility can be clearly seen in the resultant experimental charges, explaining many features previously documented in metamorphosed ores.
\end{abstract}

Keywords: metamorphosed ores, sulfide melt evolution, ore re-mobilization, immiscibility, metal alloys, sulfosalts

\section{INTRODUCTION}

Petrologists are increasingly recognizing that sulfide melts play an important role in redistributing metals and changing the tenor of metamorphosed sulfide ore deposits (e.g., Bailie \& Reid 2005, Frost et al. 2011, Tomkins \& Mavrogenes 2002, Tomkins et al. 2004, 2007). Whereas silicate wall rocks melt at the granite minimum, sulfides are so chemically variable that melting rarely occurs at a simple ternary eutectic. Therefore, any deposit rich in low melting point chalcophile elements (LMCE, particularly $\mathrm{Sb}, \mathrm{As}, \mathrm{Ag}$, and $\mathrm{Bi}$; Frost et al. 2002) that has been subjected to high-grade metamorphism is likely to have undergone partial melting. In general, ore deposits from weakly metamorphosed environments, and which are not likely to have melted, are mineralogically simple; they contain mainly pyrite, chalcopyrite, galena, and sphalerite. In contrast, melted ore bodies from high-grade metamorphic environments, such as Broken Hill, Australia; Sulitjelma, Norway (Cook 1996); Taivaljärvi, Finland (Papunen et al. 1989); and Bleikvassli, Norway (Cook et al. 1998) contain a wide variety of unusual minerals, including sulfosalts and alloys that are typically concentrated in domains that are extremely enriched in LMCE. We contend that these unusual LMCE-enriched mineral assemblages are a product of melting. Frost et al. (2011) argued that during differentiation of sulfide melt at Broken Hill, first sulfides (indicative of high sulfur fugacity), then sulfosalts, and finally metal alloys (indicative of low sulfur fugacity) crystallized. Alternatively, metal alloy melts may coexist with sulfide melts via liquid immiscibility. In this paper we investigate the relationship between sulfides, sulfosalts, and metal alloys in evolving metallic melts, either via decreasing sulfur fugacity during differentiation or via liquid immiscibility.

In addition to unusual differentiation trends, melted ore deposits also show other strange relationships. For example, one polymineralic sulfide melt inclusion from Broken Hill studied by Sparks \& Mavrogenes (2005) (their Fig. 2D) contains chalcopyrite, bornite, galena, sphalerite, arsenopyrite, gudmundite, tetrahedrite, and dyscrasite. The tetrahedrite contains only minor amounts of Ag, but it occurs with dyscrasite, a silver

$\S \quad$ Corresponding authore-mail address: John.Mavrogenes@anu.edu.au 
alloy. Furthermore, the dyscrasite, which formed from sulfur-rich melt, contains little or no sulfur. In the presence of sulfide, why did sulfur-free alloys form? Alternatively, why didn't the dyscrasite react with galena to make a $\mathrm{Pb}-\mathrm{Ag}$ sulfosalt?

Textural relations such as this are not unusual in metamorphosed ore deposits. Native $\mathrm{Sb}$ and $\mathrm{Bi}$ occur as inclusions within galena from Bleikvassli (Dobbe 1993), native $\mathrm{Ag}$ and $\mathrm{Ag}$-dominant intermetallic ores occur as inclusions within galena at Taivaljärvi (Papunen et al. 1989), and native $\mathrm{Sb}$ and $\mathrm{Ag}$ occur within a vein cutting galena in the ore from Sulitjelma (Cook 1996). What was the cause of this lack of interaction between native metals and alloys and the surrounding sulfides in these ores? Could these metal alloys and coexisting sulfides be immiscible?

A further feature of Broken Hill is the grade and distribution of Au within and around the ores. Several studies have shown that Au grades are highly variable, with the highest $\mathrm{Au}$ grades associated with an equigranular garnet-rich rock known as garnet sandstone or garnetite (Stillwell 1940). While the Broken Hill deposit as a whole averages $0.13 \mathrm{~g} / \mathrm{t} \mathrm{Au}$, garnetites range from $1.8 \mathrm{~g} / \mathrm{t}$ to $7.4 \mathrm{~g} / \mathrm{t} \mathrm{Au}$. Sulfide minerals within the Broken Hill sulfide ores contain around $2 \mathrm{~g} / \mathrm{t} \mathrm{Au}$. Comparison of $2 \mathrm{~g} / \mathrm{t} \mathrm{Au}$ in $100 \%$ sulfide ore with garnetite that contains $<2 \%$ sulfides yet has a concentration of up to $1 \mathrm{~g} / \mathrm{t} \mathrm{Au}$ suggests that something unusual is occurring within the garnetites; in fact, relative to average ore grades, sulfides (and metal alloys) within the garnetites are enriched in Au up to $300 \%$ (2 ppm in $100 \%$ versus 1 $\mathrm{ppm}$ in $<2 \%$ ). This extreme enrichment likely resulted from sulfide melt fractionation, given that the garnets themselves contain abundant sulfide melt inclusions (Sparks \& Mavrogenes 2005), and the likelihood that a rock composed entirely of garnet must have lost silicate partial melt during crystallization. Based on analyses of a series of garnetite-hosted sulfide melt inclusions from Broken Hill, Sparks \& Mavrogenes (2005) proposed that $\mathrm{Cu} / \mathrm{Pb}$ changes systematically with temperature. Thus it is a reliable monitor of crystal fractionation. In that study they found that $\mathrm{Ag}$ concentrations increased with increasing $\mathrm{Cu} / \mathrm{Pb}$, explaining why final melt segregates at Broken Hill, which occur as cross-cutting bodies called droppers, are enriched in LMCE, especially Ag (Lawrence 1967). These features demonstrate that a generalized "liquid line of descent" is needed for sulfide systems so that sulfide melt evolution can be better understood, and extreme enrichments, such as seen in Ag and Au at Broken Hill, can be explained.

The experiments we have undertaken here attempt to (1) quantify processes that fractionate sulfide melts, (2) assess the importance of liquid immiscibility, and (3) provide a liquid line of descent in $\mathrm{Pb}$ - and $\mathrm{Zn}$ - rich melts that defines partitioning between coexisting phases, mostly galena and sphalerite, that will allow assessment of the effects of crystal fractionation in natural systems.

\section{EXPERIMENTAL SET-UP}

The experiments were designed to allow a polymetallic melt to form and then evolve as it passed through a large temperature gradient. To accomplish this, we created a graphite capsule with inside dimensions of 20 $\mathrm{mm}$ by $4 \mathrm{~mm}$. An alumina sleeve was placed over the top of the capsule to separate it from the graphite heater, thus increasing the temperature gradient in the capsule (Fig. 1). We ran a calibration experiment at $820^{\circ} \mathrm{C}$ and $0.5 \mathrm{GPa}$ with crushed quartz only and a series of thermocouples covering the vertical extent of the capsule to determine the resulting temperature gradient (Fig. 1). Subsequent experiments utilized crushed quartz in the bottom 17-18 $\mathrm{mm}$ of the capsule, capped with a pressed sulfide pellet. The capsule was then covered with a graphite lid and the entire assembly was fitted into a talc sleeve. $\mathrm{An} \mathrm{MgO}$ spacer was used to ensure that the top of the capsule was located within the hot spot of the 12.7 $\mathrm{mm}$ end-loaded piston cylinder apparatus. Pressure was applied to the charge prior to heating. All experiments were heated at $50{ }^{\circ} \mathrm{C}$ per minute to $820^{\circ} \mathrm{C}$, where they were held for 2 hours. Each experiment was quenched by disconnecting the power supply to the graphite heater; the charges cooled from $820{ }^{\circ} \mathrm{C}$ to below $50{ }^{\circ} \mathrm{C}$ in 10 to 20 seconds. Capsules were then embedded in epoxy and, after the epoxy set, $2 \mathrm{~mm}$ holes were drilled at the top and the bottom of the capsule and the interior of the capsule was re-impregnated with epoxy.

Sulfide compositions were selected to be similar in composition to that found in the sulfide melt inclusions from Broken Hill studied by Sparks \& Mavrogenes (2005), and enriched in the same LMCE as Broken Hill droppers. Two slightly different starting compositions were prepared; mostly galena, sphalerite, and pyrrhotite, with added LMCE. The first (Mix 1) contained (in moles); $55 \% \mathrm{~Pb}, 16 \% \mathrm{~S}, 8 \% \mathrm{Sb}, 7 \% \mathrm{Cu}, 2 \% \mathrm{Ag}$, and $2 \%$ As, and the second (Mix 2) the same proportions with $1 \% \mathrm{Au}$. Mix 1 was used in experiments 022 and 024 and Mix 2 was used in experiment 025 .

\section{RESULTS}

At the completion of each experiment we found that the melt produced by the charge had migrated to the bottom of the chamber, leaving a series of precipitates throughout. Analysis of these precipitates revealed extreme differentiation. Initially $2 \mathrm{wt} . \% \mathrm{Ag}$ and $8 \mathrm{wt} . \%$ $\mathrm{Sb}$ were added to Exp022 in the sulfide pellet. After the experiment, both $\mathrm{Ag}$ and $\mathrm{Sb}$ were below the limit of detection in the restite, and enriched in the precipitated material. The X-ray maps in Figure 2 illustrate systematic down-hole fractionation of $\mathrm{Ag}$ (note increasing brightness from top to bottom) and extreme enrichment of $\mathrm{Sb}$ throughout the precipitates. These establish that $\mathrm{Sb}$ and $\mathrm{Ag}$ are completely mobilized during sulfide partial melting. However, more importantly, the lower 


\section{Example experiment}

\section{Graphite capsule temperature profile}

\section{Temperature $\left({ }^{\circ} \mathrm{C}\right)$}
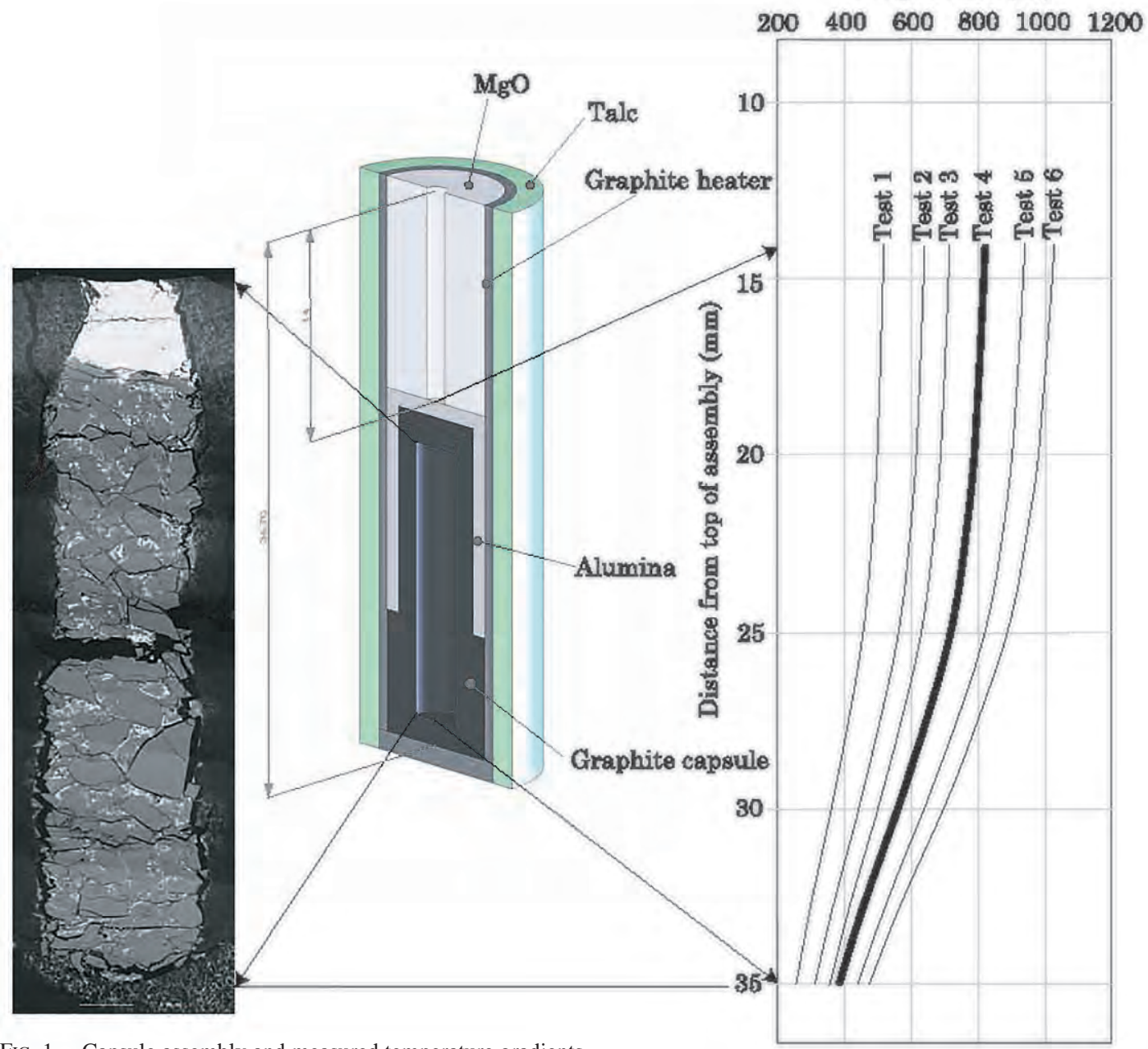

FIG. 1. Capsule assembly and measured temperature gradients.

portion of the capsule contained three melts: a sulfide melt, which crystallized galena, sphalerite, and pyrrhotite with eutectic texture; a sulfosalt melt, enriched in $\mathrm{Sb}$ and As, but which also contained significant amount of $\mathrm{S}$; and an alloy melt that contained $\mathrm{Sb}$ and $\mathrm{Ag}$ but which lacked S (Fig. 3). A close-up (experiment 024, Fig. 4) clearly shows a sphere of $\mathrm{Sb}-\mathrm{Ag}$-As melt within $\mathrm{Pb}-\mathrm{Cu}-$ $\mathrm{Sb}-\mathrm{S}$ melt that quenched to an aggregate of sulfides within the angular quartz host. This texture can only be interpreted as being formed via liquid immiscibility between alloy and sulfide melts.

\section{Equilibrium}

Although immiscibility was seen in every experiment, establishment of equilibrium is not simple in polythermal experiments. Therefore, an isothermal experiment was undertaken to establish equilibrium immiscibility at $700{ }^{\circ} \mathrm{C}$. An average bulk composition for the $700{ }^{\circ} \mathrm{C}$ isotherm was estimated for experiment 028 , and a mix of that composition was made (Table 1 ). This mix was pressed into a homogenous sulfide pellet that measured $3 \mathrm{~mm}$ diameter by $5 \mathrm{~mm}$ vertically, and heated for two hours in graphite entirely within the 


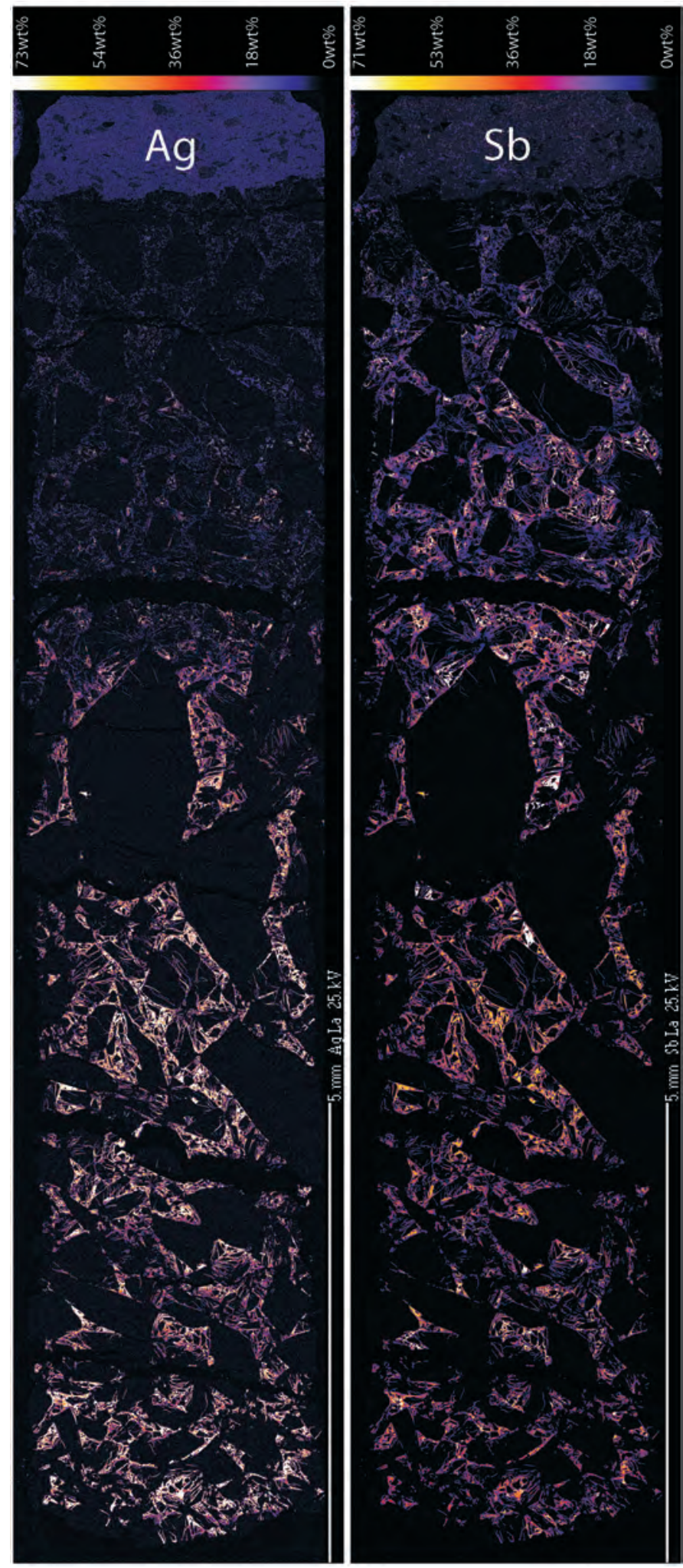

FIG. 2. Silver and Sb EMPA maps of experiment 022 . 


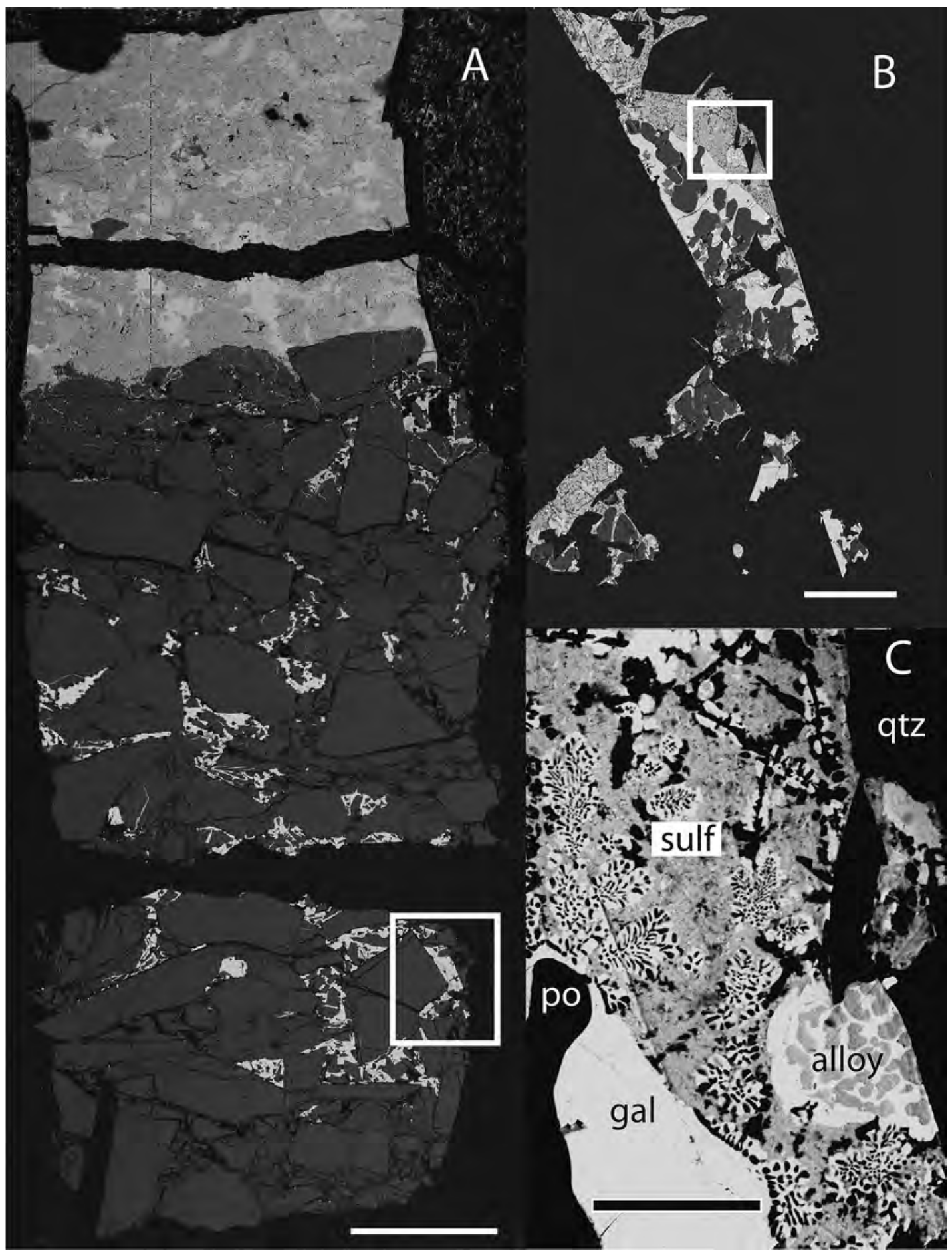

FIG. 3. Back scattered electron photomicrograph of experiment 022 (a) with detailed inset (c) showing sulfide (sulf) containing pyrrhotite (po) and galena (gal) and alloy melts in quartz (qtz) matrix. 


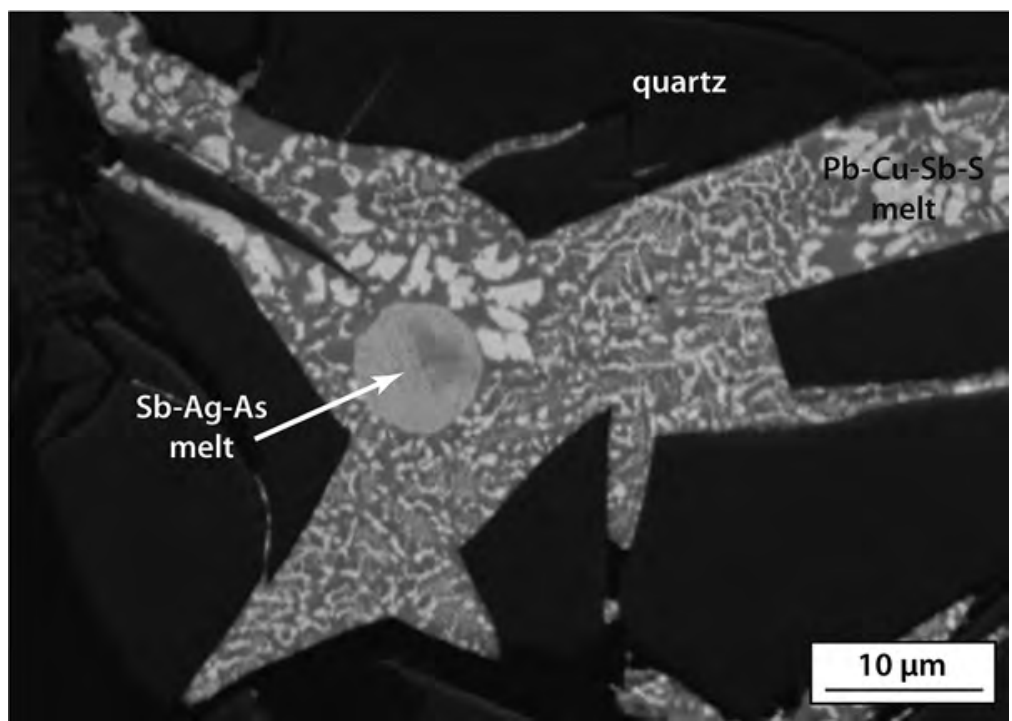

FIG. 4. Close-up of immiscible sulfide ( $\mathrm{Pb}-\mathrm{Cu}-\mathrm{Sb}-\mathrm{S})$ melt and alloy (Sb-Ag-As) melt in quartz matrix (exp024).

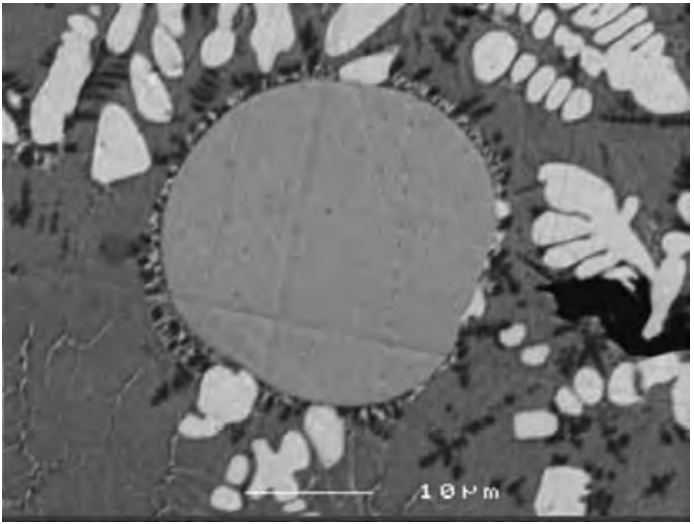

FIG. 5. Back scattered electron photomicrograph of isothermal experiment (028), showing a large immiscible alloy bled surrounded by sulfide melt and bright sulfide.

hot-spot of the piston cylinder apparatus without porous media. The quenched experimental product (Fig. 5) clearly shows immiscibility formed in this experiment at equilibrium. Furthermore, the compositions of the immiscible phases are similar to those measured in the "flow-through" experiments, whereby $\mathrm{Pb}, \mathrm{Cu}$, and $\mathrm{S}$ partition strongly into the sulfide phase and $\mathrm{Sb}$ and $\mathrm{As}$ show a strong preference for the alloy.

\section{DISCUSSION}

The experiments demonstrate that there are three types of "sulfide" melts, which in Frost et al. (2002), we called "polymetallic melts". These include: (1) True sulfide melts: Those that crystallize to form sulfides such as pyrite, pyrrhotite, chalcopyrite, galena, and sphalerite; (2) Sulfosalt melts: Those contain significant amounts of $\mathrm{Sb}$ and As and, in addition to sulfur, crystallize to form sulfosalts or a mixture of sulfosalts and sulfides; (3) Metallic melts: Those that contain virtually no sulfur, are dominated by low-melting metals such as $\mathrm{Sb}, \mathrm{As}, \mathrm{Bi}$, and $\mathrm{Te}$, and crystallize as alloys.

It should not be surprising that metal-sulfur melts will evolve to immiscibility during differentiation, since existing experimental work has shown the presence of extensive immiscibility in sulfide systems with $\mathrm{Sb}$ or As. For example, in the system $\mathrm{Ag}_{2} \mathrm{~S}-\mathrm{PbS}-\mathrm{Sb}_{2} \mathrm{~S}_{3}$ the miargyrite-galena join forms a thermal divide between sulfide melts and sulfosalt melts (Hoda \& Chang 1975). Similarly, in the CuS-Pbs- $\mathrm{Sb}_{2} \mathrm{~S}_{3}$ system the galenachalcostibite join forms a thermal divide between sulfide and sulfosalt melts (Pruseth 1995). In many sulfosalt systems, such as Ag-As-S (Roland 1970), $\mathrm{Pb}-\mathrm{Sb}-\mathrm{S}$ (Craig \& Barton 1973), and Fe-Sb-S (Barton 1971), there is a separate S-poor alloy melt that exists independent of the sulfosalt melt. Our experiments show that these three types of immiscible melt extend into complex systems and thus are characteristic of polymetallic melts in nature. 
Because the starting material was doped with much higher proportions of $\mathrm{Sb}$ than natural ore, to some extent the experiments do not duplicate the natural processes at Broken Hill and elsewhere. Because the primary ore at Broken Hill consists mainly of galena and sphalerite, and pyrrhotite with minor amounts of chalcopyrite and possibly with some pyrite, the primary melt had a composition close to $50 \mathrm{~mol} \%$ metal and $50 \mathrm{~mol} . \%$ sulfur (it would be somewhat richer in sulfur if pyrite was the primary ore). Consider melting of an ore that originally contained $200 \mathrm{ppm}$ As and Sb, which is somewhat less than the $277 \mathrm{ppm}$ average for the five lodes from the ore body (Plimer 1983). If $40 \%$ of the ore melted with a bulk distribution coefficient (D) of 0 , then the resulting melt would have $500 \mathrm{ppm}$ of these metals. We are aware that $40 \%$ melting is a bit extreme, although Frost et al. (2011) report on an ore sample from Broken Hill that would have contained at least $20 \%$ melt. We chose the high melting fraction because we wish to make a conservative estimate of the enrichment process; if the extent of melting was much smaller, the resulting melt(s) would have been much richer in $\mathrm{Sb}$ and $\mathrm{As}$. We are considering how $\mathrm{As}$ and $\mathrm{Sb}$ built up during differentiation, assuming that the melt had the eutectic composition (Mavrogenes et al. 2001) throughout. By the time that $99.5 \%$ of the melt had fractionated the residual melt would have a composition close to what was used in the experiments reported here.

These experiments show that three melts (a sulfide melt, a sulfosalt melt, and a metal melt) are involved in the crystallization of sulfosalt-doped $\mathrm{Pb}-\mathrm{Zn}-\mathrm{Fe}$ melts that are similar in composition to the the Broken Hill ore body. They provide us with a clear explanation of how such a disparate group of minerals formed at Broken Hill and other sulfide ore bodies that have undergone melting (Frost et al. 2002). The key point is that the native metal alloys of $\mathrm{Sb}, \mathrm{As}, \mathrm{Ag}$, and $\mathrm{Au}$ (and $\mathrm{Bi}$ in natural systems) formed as immiscible melts. The highest temperature sulfides at Broken Hill crystallized before an immiscible metal alloy melt formed. In the present experiments immiscible alloys formed between 690 and $600{ }^{\circ} \mathrm{C}$ in experiment 022 (Table 2) and between 785 and $765^{\circ} \mathrm{C}$ in experiment 025 (Table 3 ).

Metallic melts may persist to very low temperatures. For example, Bi solidifies at $250{ }^{\circ} \mathrm{C}$ (Liu \& Bassett 1986), the solidus in the system $\mathrm{Pb}-\mathrm{Sb}-\mathrm{S}$ is below 240 ${ }^{\circ} \mathrm{C}$ (Craig \& Barton 1973), in the system Ag-Au-Te the solidus is below $350{ }^{\circ} \mathrm{C}$ (Cabri 1965), and dyscrasite-

ABLE 1. COMPOSITIONS (mol.\%) OF STARTING MIX (MIX), AVERAGE ALLOY COMPOSITION (ALLOY) AND AVERAGE QUENCHED MELT (MELT) FOR $700^{\circ} \mathrm{C}$ ISOTHERMAL EXPERIMENT 028

\begin{tabular}{lllllllll}
\hline Exp028 & $\mathrm{S}$ & $\mathrm{Fe}$ & $\mathrm{Cu}$ & $\mathrm{As}$ & $\mathrm{Ag}$ & $\mathrm{Sb}$ & $\mathrm{Pb}$ & $\mathrm{TOTAL}$ \\
\hline mix & 28.90 & 1.67 & 16.16 & 6.23 & 2.59 & 31.40 & 13.05 & 100 \\
alloy & 1.29 & 0.00 & 3.91 & 10.97 & 1.41 & 80.99 & 1.42 & 100 \\
melt & 40.06 & 2.73 & 31.26 & 0.30 & 1.20 & 1.24 & 13.21 & 100 \\
\hline
\end{tabular}

TABLE 2. COMPOSITIONS (mol.\%) OF THE UNMELTED PLUG (RESTITE), STARTING MIX (MIX), CUMULATE GALENA (GALENA), QUENCHED MELT (MELT), AND ALLOY AS A FUNCTION OF TEMPERATURE (DETERMINED BY DISTANCE DOWN THE CAPSULE) FOR EXPERIMENT 022

\begin{tabular}{|c|c|c|c|c|c|c|c|c|c|c|c|}
\hline Exp022 & $T\left({ }^{\circ} \mathrm{C}\right)$ & $\mathrm{S}$ & $\mathrm{Fe}$ & $\mathrm{Cu}$ & $\mathrm{Zn}$ & As & $\mathrm{Ag}$ & $\mathrm{Sb}$ & $\mathrm{Pb}$ & Sum & $\mathrm{Cu} / \mathrm{Pb}$ \\
\hline restite & & 44.7 & 6.30 & bdl & 15.0 & 2.16 & bdl & 0.73 & 30.0 & 98.9 & \\
\hline starting mix & & 43.7 & 7.16 & 9.42 & 6.61 & 2.85 & 1.65 & 5.71 & 22.9 & 100.0 & 0.41 \\
\hline \multirow[t]{4}{*}{ galena } & 395 & 47.9 & 0.06 & 3.7 & 1.28 & 0.03 & 1.66 & 1.08 & 44.3 & 100.0 & 0.08 \\
\hline & 400 & 49.1 & bdl & 1.79 & bdl & bdl & 1.17 & 1.03 & 46.9 & 100.0 & 0.04 \\
\hline & 435 & 48.8 & 0.21 & 1.53 & 0.74 & 0.06 & 1.55 & 1.41 & 45.7 & 100.0 & 0.03 \\
\hline & 520 & 50.2 & bdl & 0.84 & bdl & bdl & 1.12 & 1.25 & 46.6 & 100.0 & 0.02 \\
\hline \multirow[t]{4}{*}{ melt } & 395 & 40.9 & bdl & 33.4 & bdl & 0.4 & 8.21 & 9.58 & 7.48 & 100.0 & 4.47 \\
\hline & 400 & 44.0 & 0.03 & 30.3 & bdl & 0.28 & 3.85 & 10.4 & 11.1 & 100.0 & 2.73 \\
\hline & 435 & 43.5 & 0.14 & 30.9 & 0.13 & 0.19 & 3.06 & 11.1 & 10.9 & 99.9 & 2.83 \\
\hline & 520 & 44.8 & 1.10 & 25.2 & 0.26 & 0.36 & 4.50 & 10.4 & 13.4 & 100.0 & 1.88 \\
\hline \multirow[t]{2}{*}{ alloy } & 600 & 44.1 & 1.30 & 25.0 & bdl & 0.78 & 3.92 & 11.4 & 13.5 & 100.0 & 1.85 \\
\hline & 690 & 45.8 & 1.75 & 22.9 & bdl & 0.35 & 3.41 & 9.65 & 16.2 & 100.1 & 1.41 \\
\hline
\end{tabular}


TABLE 3. COMPOSITIONS (mol.\%) OF THE UNMELTED PLUG (RESTITE), STARTING MIX (MIX), QUENCHED MELT (MELT), AND ALLOY AS A FUNCTION OF TEMPERATURE (DETERMINED BY DISTANCE DOWN THE CAPSULE) FOR EXPERIMENT 025

\begin{tabular}{|c|c|c|c|c|c|c|c|c|c|c|c|c|}
\hline Exp025 & $T\left({ }^{\circ} \mathrm{C}\right)$ & $\mathrm{S}$ & $\mathrm{Fe}$ & $\mathrm{Cu}$ & $\mathrm{Zn}$ & As & $\mathrm{Ag}$ & $\mathrm{Sb}$ & $\mathrm{Au}$ & $\mathrm{Pb}$ & Sum & $\mathrm{Cu} / \mathrm{Pb}$ \\
\hline restite & & 47.1 & 7.32 & bdl & 15.0 & 1.35 & bdl & 0.73 & 0.4 & 28.3 & 100.2 & \\
\hline $\operatorname{mix}$ & & 43.5 & 7.13 & 9.38 & 6.56 & 2.84 & 1.65 & 5.68 & 0.44 & 22.8 & 100.0 & 0.41 \\
\hline \multirow[t]{6}{*}{ melt } & 465 & 43.1 & 0.29 & 31.4 & bdl & 1.01 & 5.24 & 10.4 & 0.38 & 8.11 & 99.9 & 3.87 \\
\hline & 470 & 42.7 & bdl & 28.5 & bdl & 1.20 & 9.28 & 9.80 & 0.33 & 8.28 & 100.1 & 3.44 \\
\hline & 525 & 43.4 & 1.12 & 26.9 & bdl & 0.98 & 4.65 & 10.1 & 0.39 & 12.5 & 100.0 & 2.15 \\
\hline & 530 & 43.7 & 0.89 & 26.7 & bdl & 0.86 & 4.38 & 10.3 & 0.31 & 12.8 & 99.9 & 2.09 \\
\hline & 555 & 44.3 & 0.95 & 26.1 & 0.09 & 1.00 & 4.30 & 9.80 & 0.26 & 13.2 & 100.0 & 1.98 \\
\hline & 770 & 47.1 & 6.04 & 20.5 & 1.45 & 0.63 & 1.38 & 7.68 & 0.22 & 15 & 100.0 & 1.37 \\
\hline \multirow[t]{4}{*}{ alloy } & 765 & bdl & 0.63 & 2.33 & 0.29 & 29.2 & 2.19 & 49.7 & 15.4 & 0.34 & 100.1 & 6.85 \\
\hline & 770 & bdl & 0.29 & 1.42 & 0.44 & 30.6 & 2.68 & 51.5 & 12.8 & 0.37 & 100.1 & 3.84 \\
\hline & 780 & bdl & bdl & 3.72 & bdl & 35 & 0.84 & 48.7 & 8.05 & 3.67 & 100.0 & 1.01 \\
\hline & 785 & bdl & 1.00 & 4.05 & bdl & 31.5 & 1.62 & 50.8 & 6.74 & 4.25 & 100.0 & 0.95 \\
\hline
\end{tabular}

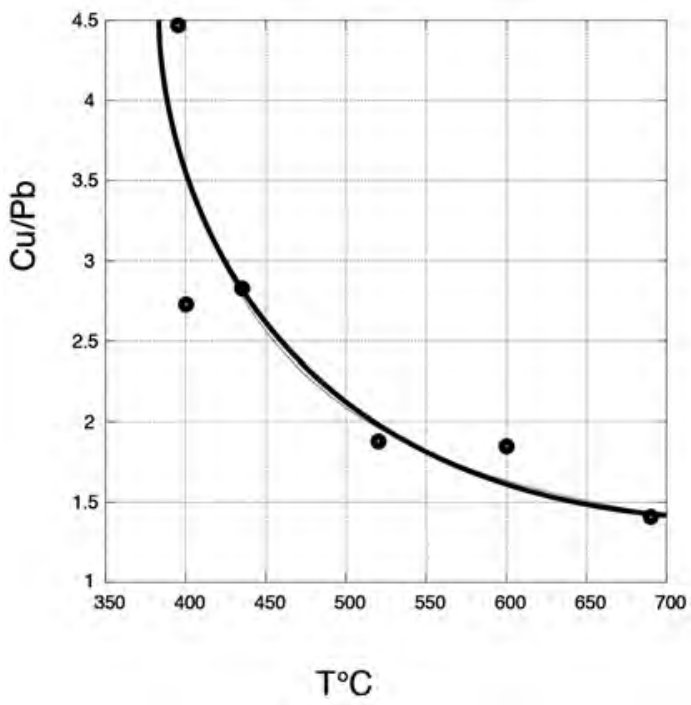

FIG. 6. $\mathrm{Cu} / \mathrm{Pb}$ versus $\mathrm{T}\left({ }^{\circ} \mathrm{C}\right)$ of quenched melt in exp022

antimony melts at $485{ }^{\circ} \mathrm{C}$ (Keighin \& Honea 1969). Thus the last dregs of a sulfide melt are likely to be a metallic melt and immiscibility is a very efficient way to extract the metallic melt from a sulfide or sulfosalt melt.

Considering that PdTe has a eutectic at $490{ }^{\circ} \mathrm{C}$ (Elliott 1965), it is not surprising that PGEs in association with $\mathrm{Bi}$ and $\mathrm{Te}$ are highly enriched in late stage metallic melts associated with large orthomagmatic sulfide deposits such as Bushveld (Holwell \& McDonald 2007) and Sudbury (Dare et al. 2010). The global distribution of sulfosalt minerals is also quite informative. They are found in significant abundance in evolved metallic melts of either metamorphic or magmatic origin (Frost et al. 2002) due to the processes documented herein, or in magmatic vapor deposits (Henley et al. 2011) due to the high solubility of semimetals such as $\mathrm{As}$ and $\mathrm{Sb}$ in vapor.

Sulfide melt fractionation is also clarified by the experiments reported here. The current work shows that galena crystallization causes $\mathrm{Cu}$ concentrations in sulfide melt to increase while $\mathrm{Pb}$ concentrations decrease during evolution down temperature (Fig. 6). During evolution Ag acts incompatibly, increasing in concentration as $\mathrm{Cu} / \mathrm{Pb}$ increases (Fig. 7). Additionally, $\mathrm{Fe}$ and $\mathrm{Zn}$ concentrations are nearly absent from sulfide partial melts and, when present, decrease rapidly with fractionation, presumably because of the crystallization of sphalerite. These trends can be used to assess the extent of melting in established metamorphic regions and track sulfide melt evolution where numerous cross-cutting veins complicate genetic interpretations. Analyses of galena crystalized in these experiments reveal the presence of $\mathrm{Cu}(0.84$ to $3.7 \%)$ and $\mathrm{Zn}(0.06$ to $1.28 \%$ ) (Table 2), two elements not found in the structure of galena formed hydrothermally (Foord 1989). Galena compositions could, therefore, be used to determine if sulfide melting occurred in a terrane whose metamorphic history is unknown, or where sulfide melts may have migrated into lower temperature regimes. Finally, the results show significant enrichment of $\mathrm{Au}$ in the metal alloy of experiment 025 (Table 3). Note that while the sulfides contain low levels of $\mathrm{Au}$ (on the order of $0.3 \%$, Table 3 ), the alloy contains up to $15.4 \% \mathrm{Au}$. This extreme enrichment explains how the garnetites at Broken Hill are low in sulfide while enriched in Au. More generally, this illustrates the power of immiscible alloys to concentrate metals from sulfide melt and may 


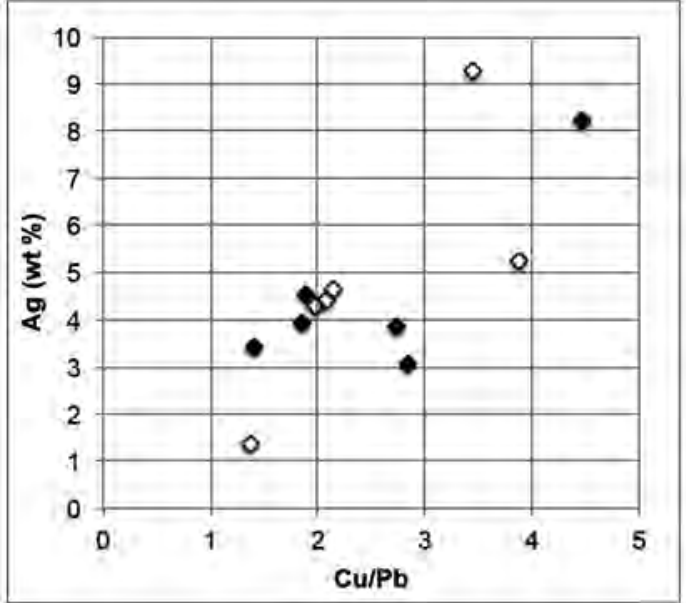

FIG. 7. Ag versus $\mathrm{Cu} / \mathrm{Pb}$ of quenched melt in exp022 (filled symbols) and exp025 (open symbols)

explain, more generally, how odd sulfosalt/alloy assemblages are produced globally.

\section{REFERENCES}

BAILIE, R.H. \& ReID, D.L. (2005) Ore textures and possible sulphide partial melting at Broken Hill, Aggeneys, South Africa I: Petrography. South African Journal of Geology 108(1), 51-70.

Barton, P.B. (1971) Fe-Sb-S system. Economic Geology 66(1), 121-132.

CABRI, L.J.P. (1965) Discussion of 'Empressite and stuetzite redefined' by RM Honea. American Mineralogist 50(5-6), 795-801.

Cook, N.J. (1996) Mineralogy of the sulphide deposits at Sulitjelma, northern Norway. Ore Geology Reviews 11(5), 303-338.

Cook, N.J., Spry, P.G., \& Vokes, F.M. (1998) Mineralogy and textural relationships among sulphosalts and related minerals in the Bleikvassli $\mathrm{Zn}-\mathrm{Pb}-(\mathrm{Cu})$ deposit, Nordland, Norway. Mineralium Deposita 34(1), 35-56.

Craig, J.R. \& Barton, P.B. (1973) Thermochemical approximations for sulfosalts. Economic Geology 68(4), 493-506.

DAre, S.A.S., Barnes, S.J., Prichard, H.M., \& Fisher, P.C.(2010) The Timing and Formation of Platinum-Group Minerals from the Creighton Ni-Cu-Platinum-Group Element Sulfide Deposit, Sudbury, Canada: Early Crystallization of PGE-Rich Sulfarsenides. Economic Geology 105(6), 1071-1096.
Dobbe, R. (1993) Bismuth tellurides (joseite-B, bismuthian tsumoite) in a $\mathrm{Pb}-\mathrm{Zn}$ deposit from Tunaberg, Sweden. European Journal of Mineralogy 5, 165-170.

Elliott, R.P. (1965) Constitution of Binary Alloys, First Supplement. New York, McGraw-Hill.

Foord, E.E. \& Shawe, D.R. (1989) The Pb-Bi-Ag-Cu-(Hg) chemistry of galena and some associated sulfosalts: a review and some new data from Colorado, California and Pennsylvania. Canadian Mineralogist 27, 363-382.

Frost, B.R., Mavrogenes, J.A., \& Tomkins, A.G. (2002) Partial melting of sulfide ore deposits during medium- and high-grade metamorphism Canadian Mineralogist 40, $1-18$.

Frost, B.R., Swapp, S.M., \& Mavrogenes, J. (2011) Textural Evidence for Extensive Melting of the Broken Hill Orebody. Economic Geology 106(5), 869-882.

Henley, R.W., Mavrogenes, J., \& Tanner, D. (2011) Sulfosalt melts and heavy metal (As-Sb-Bi-Sn-Pb-Tl) fractionation during volcanic gas expansion: the El Indio (Chile) paleo-fumarole. Geofluids 12, 199-215.

Hoda, S.N. \& Chang, L.L.Y. (1975) Phase relations in the systems $\mathrm{PbS}-\mathrm{Ag}_{2} \mathrm{~S}-\mathrm{Sb}_{2} \mathrm{~S}_{3}$ and $\mathrm{PbS}-\mathrm{Ag}_{2} \mathrm{~S}-\mathrm{Bi}_{2} \mathrm{~S}_{3}$. American Mineralogist 60(7-8), 621-633.

Holwell, D.A. \& McDonALD, I. (2007) Distribution of platinum-group elements in the Platreef at Overysel, northern Bushveld Complex: a combined PGM and LA-ICP-MS study. Contributions to Mineralogy and Petrology 154(2), 171-190.

Keighin, C.W. \& HoneA, R. M.(1969) System Ag-Sb-S from 600 degrees $\mathrm{C}$ to 200 degrees C. Mineralium Deposita 4(2), 153-171.

LAWRENCE, L. (1967) Sulfide neomagmas in highly metamorphosed sulfide ore deposits. Mineralium Deposita 2(2), 5-10.

LiU, L.-G.\& BAssetT, W.A. (1986) Elements, Oxides, and Silicates: High Pressure Phases with Implications for the Earth's Interior. Oxford University Press, New York, N.Y.

Mavrogenes, J.A., MacIntosh, I.W., \& Ellis, D.J. (2001) Partial melting of the Broken Hill galena-sphalerite ore: Experimental studies in the system PbS-FeS-ZnS- $\left(\mathrm{Ag}_{2} \mathrm{~S}\right)$. Economic Geology and the Bulletin of the Society of Economic Geologists 96(1), 205-210.

Papunen, H., Kopperoinen, T., \& Tuokko, I. (1989) The Taivaljärvi Ag-Zn deposit in the Archean greenstone belt, Eastern Finalnd. Economic Geology 84, 1262-1276.

Plimer, I. (1983) Minerals of the primary ore. In Minerals of Broken Hill (H.K. Worner and R.W, Mitchell., eds.). Australian Mining and Smelting Ltd., Melbourne, Australia (50-57). 
Pruseth, K.L., Mishra, B. \& Bernhardt, H.-J. (1995) Phase relations in the $\mathrm{Cu}_{2} \mathrm{~S}-\mathrm{PbS}-\mathrm{Sb}_{2} \mathrm{~S}_{3}$ system: an experimental appraisal and application to natural polymetallic sulfide ores. Economic Geology 90, 720-732.

Roland, G.W. (1970) Phase relations below 575 degrees C in the system Ag-AS-S. Economic Geology 65(3), 241-252

SPARKS, H.A. \& MAVRogENES, J.A. (2005) Sulfide melt inclusions as evidence for the existence of a sulfide partial melt at Broken Hill, Australia. Economic Geology 100(4), 773-779.

STILLWELl, F. (1940) The occurrence of gold in the Broken Hill lode. Proceedings of the Australian Institutes of Mining and Metallurgy 117, 23-28.

Tomkins, A.G. \& Mavrogenes, J.A. (2002) Mobilization of gold as a polymetallic melt during pelite anatexis at the
Challenger deposit, South Australia: A metamorphosed Archean gold deposit. Economic Geology and the Bulletin of the Society of Economic Geologists 97(6), 1249-1271.

Tomkins, A.G., Pattison, D.R.M., \& Zaleski, E. (2004) The Hemlo gold deposit, Ontario: An example of melting and mobilization of a precious metal-sulfosalt assemblage during amphibolite facies metamorphism and deformation. Economic Geology 99(6), 1063-1084.

Tomkins, A., Pattison, D.R.M., \& Frost, B.R. (2007) On the initiation of metamorphic sulfide anatexis. Journal of Petrology 48(3), 511-535.

Received March 22, 2013. Revised manuscript received September 9, 2013. Second revision accepted January $10,2014$. 